\title{
Trends in HIV prevalence and sexual behaviour among young people aged $15-24$ years in countries most affected by HIV
}

\author{
The International Group on Analysis of Trends in HIV Prevalence and Behaviours in \\ Young People in Countries most Affected by HIV
}

\section{Correspondence to Dr Eleanor Gouws, Strategic Intelligence and Analysis Division, UNAIDS, 20 Avenue Appia, 1211 Geneva, Switzerland; gouwse@unaids.org}

\section{The International Group on} Analysis of Trends in HIV Prevalence and Behaviours in Young People in Countries most Affected by HIV: PD Ghys, E Gouws, R Lyerla (UNAIDS Geneva): JM Garcia-Calleja (WHO Geneva); B Barrerre (ICF Macro: Measure DHS

Maryland, USA); D Serrano, C Velasquez (Angola):

C Deleveaux (Bahamas); W Gill, M Mmelesi (Botswana); A Niyongere (Burundi); E Mboui Bilon (Cameroun); J de D Longo, M Massanga (Central African Republic); D Guidaoussou (Chad); JP Konan Diby (Côte d'Ivoire); N Kibangou (Djibouti); Aseged Woldu (Ethiopia); F Bikoma (Gabon); N Duval, K Spring (Haiti); A Barsigo (Kenya); J Nkonyana (Lesotho); N Wandonda (Malawi). Mozambique Multisectoral Technical Group (Mozambique): A Jonas (Namibia); I Kawu (Nigeria); M Mutagoma (Rwanda); T Mosala (South Africa); S Mndzebele, H Odido (Swaziland); YD Agbogan (Togo); J Musinguzi (Uganda); G Somi (UR Tanzania); M Gboun, D Phiri (Zambia): E Gonese, S Gregson, 0 Mugurungi (Zimbabwe).

Accepted 3 October 2010

\section{ABSTRACT}

Background The 2001 United Nations (UN) Declaration of Commitment goal to reduce HIV prevalence among young people by $25 \%$ by 2010 was signed by 189 countries. Progress towards this goal is assessed. Changes in reported sexual behaviour among young people aged 15-24 years are also investigated. Methods Thirty countries were invited to participate in the study. HIV prevalence trends were assessed using data from antenatal clinic (ANC) surveillance and from repeat national surveys between 2000 and 2008. Regression analysis was used to determine if the UN target has been reached. Trends in sexual behaviour were analysed using data from repeat national surveys between 1990 and 2008.

Results Seven countries showed significant prevalence declines of $25 \%$ or more among ANC attendees by 2008 , in rural or urban areas or both. Three further countries showed a significant decline in prevalence among young women or men in national surveys. Four countries are unlikely to reach the UN goal. Nine countries did not have adequate data to assess prevalence trends. Favorable changes in sexual behaviour were observed in the majority of countries. In eight countries with significant declines in HIV prevalence, significant changes were also observed in sexual behaviour among either men or women

Conclusions Declines in HIV prevalence among young people were documented in the majority of countries with adequate data and in most cases were accompanied by changes in sexual behaviour. Further data and more rigorous analysis are needed to understand associations between interventions, behavioural changes and changes in HIV prevalence/ incidence.

Considerable progress has been made towards scaling up access to HIV treatment, care and support with approximately 1 million people newly receiving antiretroviral therapy (ART) in low and middle income countries in 2008. ${ }^{1}$ However, the estimated global number of new infections remains unacceptably high at approximately 2.7 million in $2008 .^{2}$

A primary goal of the global response to HIV is to prevent new infections. To date, HIV prevalence data have been used to monitor trends in the HIV epidemic, but the rapid improvements in providing ART to people in need and the resulting increase in survival times are making it more difficult to rely on prevalence data only. Incidence data (or the rate at which new infections occur) are more valuable as it provides a more sensitive measure for evaluating changes in the HIV epidemic over time and for measuring the impact of interventions on infection levels.

There are three main approaches to determine HIV incidence in populations: direct measurement in cohort studies; mathematical inference from prevalence data; or using biological assays for recent infection in cross-sectional surveys. Following cohorts of uninfected individuals until seroconversion is often regarded as the 'gold standard' for measuring the incidence of infection or disease. However, these studies are typically conducted in small areas only, are logistically difficult to carry out, and are subject to bias because of the selection of initial participants and those remaining in the cohort and because of the effect of intensified interventions in the cohort. Several statistical and mathematical models to estimate HIV incidence using prevalence data and assumptions about mortality have been described and are regularly applied in countries. ${ }^{3-7}$ Several biological assays and testing strategies based on HIV antigen, RNA or antibody measurement have also been developed over recent years to distinguish recent from established HIV infections. ${ }^{8} 9$ Whereas some of these methods have been used in several settings across the world, work still needs to be done to validate and calibrate assays and algorithms for estimating incidence from cross-sectional collection of blood specimens. $^{10}$

Trends in HIV prevalence in a population of newly exposed individuals could be regarded as a reasonable proxy for assessing trends in HIV incidence, despite several limitations. ${ }^{11}$ Prevalent infections among young people aged 15-24 years are assumed to be recent because the onset of sexual activity in this age group is recent. In addition, mortality effects in this age group are typically small so that trends in HIV prevalence are more likely to reflect trends in incidence rather than trends in mortality. ${ }^{12}$

In 2001, 189 member states signed the Declaration of Commitment at the United Nations General Assembly Special Session (UNGASS) on AIDS, and committed to achieving a $25 \%$ reduction in HIV prevalence among 15-24-year-old people in the 25 most affected countries by 2005 and globally by 2010 (UNGASS indicator number 22). ${ }^{13}$

This study assesses progress towards this UNGASS target. In countries most affected by the epidemic, changes in HIV prevalence among young pregnant women aged 15-24 years attending unlocked scheme, see http://sti. bmi.com/site/about/unlocked. xhtml 
antenatal clinics (ANC) are analysed, as recommended in the guidelines for monitoring the UNGASS indicators. ${ }^{14}$ In addition, changes in HIV prevalence among 15-24-year-old women and men participating in repeated national population-based surveys (referred to as 'HIV prevalence surveys' in the remainder of this paper) are analysed. Changes in sexual behaviour among young people, as reported in national population-based behavioural surveys conducted over time (referred to as 'behavioural surveys' in the remainder of this paper), are also analysed and an assessment is made of the concordance of HIV prevalence trends and sexual behaviour trends.

\section{METHODS}

\section{Prevalence data}

All countries with an estimated national adult HIV prevalence of greater than $2 \%$ in the general population in $2007^{2}$ were invited to participate in this study. Data on HIV prevalence among 15-24-year-old pregnant women included in ANC surveillance were collated for statistical analysis of prevalence trends. To avoid potential bias as a result of expanding ANC surveillance over time, only data from those sites that were consistently included in surveillance between 2000 and 2008 were included in the analysis. In South Africa, data were only available aggregated at the provincial level and not by individual site, so that the provincial level trend data were included in the analysis.

Exponential trend lines were fitted to prevalence data for each country using data collected from sites that were consistently included in sentinel surveillance during the period of interest (2000-8), first to assess whether there have been changes in HIV prevalence over recent years and second to assess if these changes are statistically significant. The regression analysis was done only for those countries where prevalence data were

Table 1 Available data on HIV prevalence and behaviour among young people aged 15-24 years over time in countries with national adult prevalence of $2 \%$ or greater in 2007

\begin{tabular}{|c|c|c|c|c|c|c|c|c|}
\hline \multirow[b]{2}{*}{ Country } & \multirow[b]{2}{*}{$\begin{array}{l}\text { Adult HIV } \\
\text { prevalence } \\
\text { in } 2007(\%) \\
\text { (as per the } \\
2008 \text { Global } \\
\text { Report) }\end{array}$} & \multirow[b]{2}{*}{$\begin{array}{l}\text { Repeat national } \\
\text { HIV prevalence } \\
\text { surveys } \\
\text { conducted } \\
\text { since } 2000\end{array}$} & \multirow[b]{2}{*}{$\begin{array}{l}\text { Prevalence } \\
\text { available from ANC } \\
\text { surveillance: years } \\
\text { in which surveillance } \\
\text { was done }\end{array}$} & \multirow{2}{*}{\multicolumn{2}{|c|}{$\begin{array}{l}\text { No of sites } \\
\text { that were } \\
\text { consistently } \\
\text { included in } \\
\text { ANC } \\
\text { surveillance } \\
\text { urban/rural }\end{array}$}} & \multicolumn{3}{|c|}{$\begin{array}{l}\text { Behavioural data collected from young men and women } \\
\text { (15-24 years) in national surveys }\end{array}$} \\
\hline & & & & & & $\begin{array}{l}\text { Age of first sex } \\
\text { by the age of } \\
15 \text { years (among } \\
\text { those aged } \\
15-19 \text { years) }\end{array}$ & $\begin{array}{l}\text { Condom use during } \\
\text { last sex act among } \\
\text { those with multiple } \\
\text { partners in past } \\
12 \text { months }\end{array}$ & $\begin{array}{l}\text { Sexual } \\
\text { intercourse with } \\
\text { more than one } \\
\text { partner in past } \\
12 \text { months }\end{array}$ \\
\hline Angola & 2.1 & & 2004, 2005, 2007 & 18 (national) & & NA & NA & NA \\
\hline Bahamas & 3.0 & & Every year 2000-8 & 8 & - & NA & NA & NA \\
\hline Belize & 2.1 & & NA & & & NA & NA & NA \\
\hline Botswana & 23.9 & 2004, 2008 & $\begin{array}{l}2001,2002,2003,2005 \\
2006\end{array}$ & 10 & 13 & NA & NA & NA \\
\hline Burundi & 2.0 & 2002, 2007 & Every year 2000-7 & 4 & 4 & 1987,2005 & NA & NA \\
\hline Cameroon & 5.1 & & NA & & & 1998, 2004, 2006 & 1998, 2004 & 1998, 2004 \\
\hline CAR & 6.3 & & 2006 & & & 1994,2006 & 2006 & 2006 \\
\hline Chad & 3.5 & & 2002, 2003 & & & 1997, 2004 & 1997, 2004 & 1997, 2004 \\
\hline Congo & 3.5 & & NA & & & 2005 & 2005 & 2005 \\
\hline Cote d'Ivoire & 3.9 & & $\begin{array}{l}\text { 2000, 2001, 2002, 2004, } \\
\text { 2005, } 2008\end{array}$ & 11 & 16 & $1994,1998,2005$ & 1998,2005 & 1998,2005 \\
\hline Djibouti & 3.1 & & NA by site & & & NA & NA & NA \\
\hline Ethiopia & 2.1 & & $2001,2002,2003,2005$ & 20 & 9 & 2000, 2005 & 2000,2005 & 2000,2005 \\
\hline Gabon & 5.9 & & 2003, 2007 & & & 2000 & 2000 & 2000 \\
\hline Guyana & 2.5 & & NA & & & NA & NA & NA \\
\hline Haiti & 2.2 & & 2000, 2004, 2007 & 8 & 9 & 1994, 2000, 2005 & 2000, 2005 & 2000, 2005 \\
\hline Kenya & $7.1-8.5$ & 2003, 2007 & Every year $2000-5$ & 21 & 13 & 1993, 1998, 2003 & 1998, 2003 & 1998, 2003 \\
\hline Lesotho & 23.2 & & 2003, 2005, 2007 & 2 & 8 & 2004 & 2004 & 2004 \\
\hline Malawi & 11.9 & & $\begin{array}{l}\text { 1999, 2002, 2003, 2005, } \\
2007\end{array}$ & 11 & 8 & 2000, 2004, 2006 & 2000, 2004 & 2000, 2004 \\
\hline Mozambique & 12.5 & & 2001, 2002, 2004, 2007 & $\begin{array}{l}11 \text { (south), } \\
16 \text { (central), } \\
11 \text { (north) }\end{array}$ & & 1997, 2003 & 2003 & 2003 \\
\hline Namibia & 15.3 & & $2002,2004,2006,2008$ & 13 & 8 & 1992, 2000, 2006 & 2000,2006 & 2000,2006 \\
\hline Nigeria & 3.1 & & 2003, 2005, 2008 & 87 & 75 & $1990,1999,2003$ & 2003 & 2003 \\
\hline Rwanda & 2.8 & & 2002, 2003, 2005, 2007 & 11 & 13 & $1992,2000,2005$ & NA & 2000, 2005 \\
\hline South Africa & 18.1 & $\begin{array}{l}2002,2005, \\
2008\end{array}$ & Every year 2000-7 & $\begin{array}{l}\text { Aggregated } \\
\text { for nine } \\
\text { provinces }\end{array}$ & & NA & NA & $2002,2005,2008$ \\
\hline Suriname & 2.4 & & NA & & & NA & NA & NA \\
\hline Swaziland & 26.1 & & 2002, 2004, 2006, 2008 & 9 & 8 & 2007 & 2007 & 2007 \\
\hline Togo & 3.3 & & 2003, 2004, 2006, 2008 & 18 & 16 & $N A$ & NA & NA \\
\hline Uganda & 5.4 & & $\begin{array}{l}\text { 2000, 2001, 2002, 2005, } \\
\text { 2006, } 2007\end{array}$ & 9 & 11 & $\begin{array}{l}1995,2000,2004 \\
2006\end{array}$ & 1995, 2000, 2006 & 1995, 2000, 2006 \\
\hline UR Tanzania & 6.2 & $2003-4,2007$ & $2002,2004,2006$ & 24 & 33 & $\begin{array}{l}\text { 1992, 1996, 1999, } \\
2004,2007\end{array}$ & $\begin{array}{l}1996,1999,2004 \\
2007\end{array}$ & $\begin{array}{l}1996,1999,2004, \\
2007\end{array}$ \\
\hline Zambia & 15.2 & 2002, 2007 & $2002,2004,2006$ & 11 & 11 & $\begin{array}{l}1992,1996,2002, \\
2007\end{array}$ & 1996, 2002, 2007 & 1996, 2002, 2007 \\
\hline Zimbabwe & 15.3 & 2002, 2006 & $\begin{array}{l}2000,2001,2002,2004, \\
2006\end{array}$ & 7 & 7 & 1994, 1999, 2005 & 1999, 2005 & 1999, 2005 \\
\hline
\end{tabular}


A

Botswana

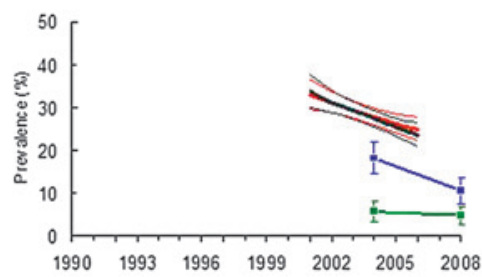

Mozambique
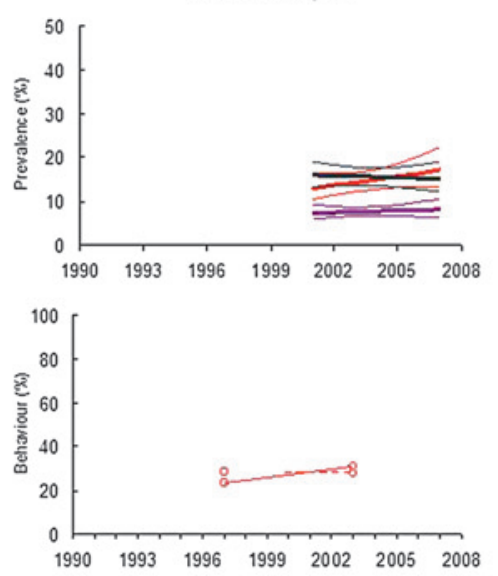

Swaziland

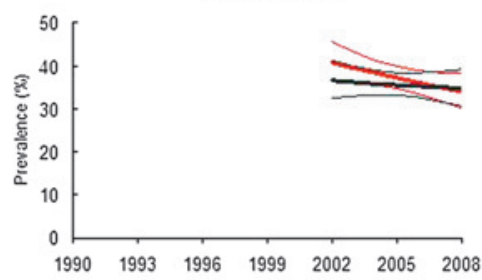

Southern Africa

Lesotho
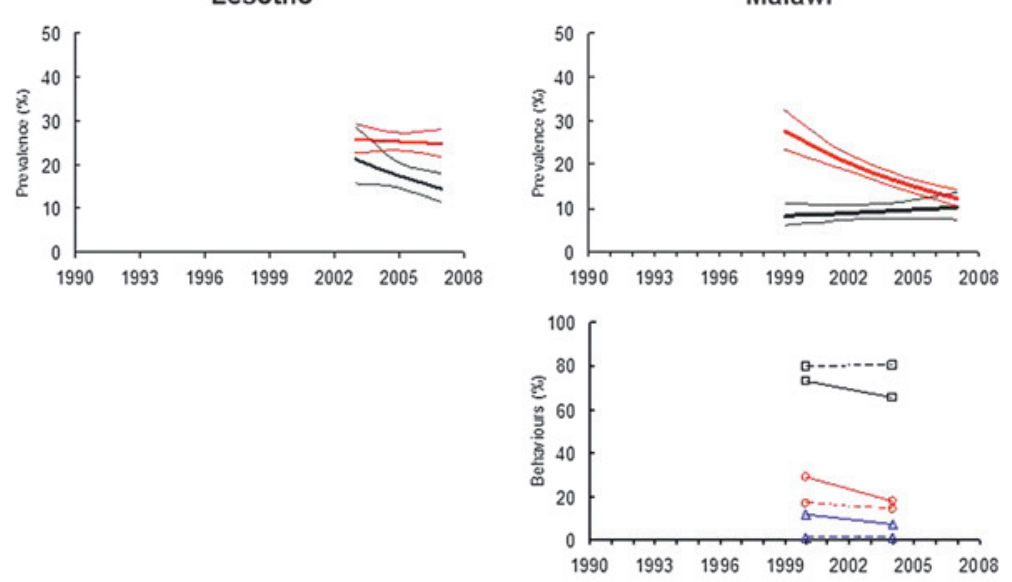

South Africa
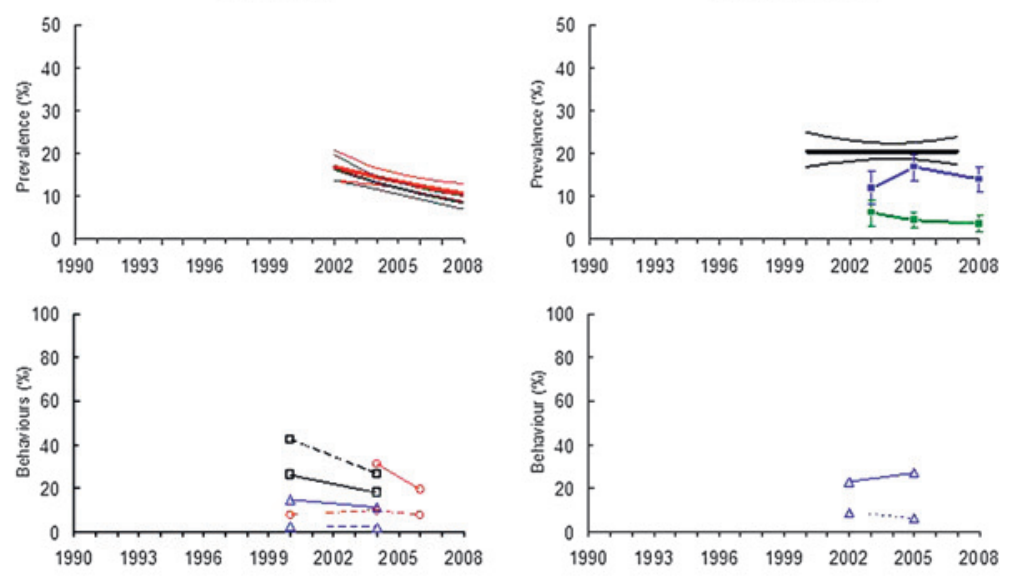

Zambia

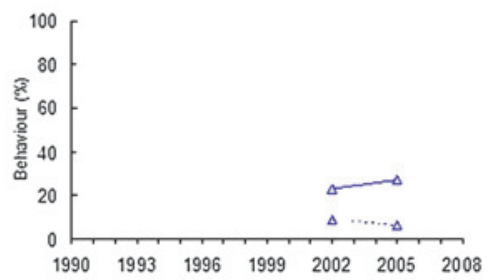

Zimbabwe
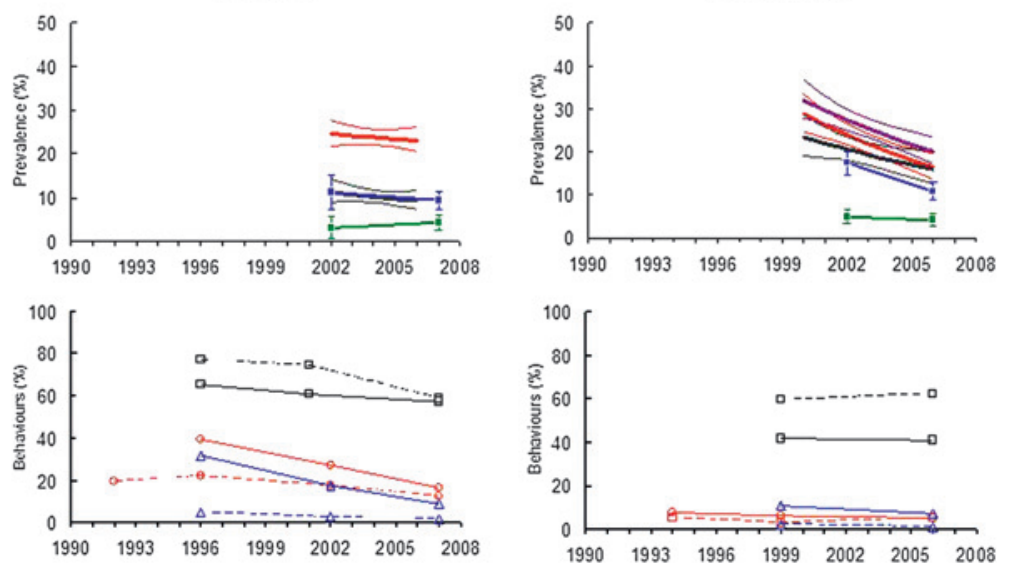

Had sex byage 15 (ages 15-19)

-a- Fernale

- Male

More than 1 sex partner the last 12 months (ages 15-24)

$-\Delta-$ Fernale

$\triangle$ Male

More than 1 sex partner the last 12 months and did not use a condom (ages 15-24)

-to- Fernak $\rightarrow-$ Male

Figure 1 Trends in HIV prevalence and selected sexual behaviour indicators among young men and women aged 15-24 years in (A) southern Africa, (B) east Africa, (C) central Africa, (D) west Africa and (E) the Caribbean. 
B

\section{Burundi}
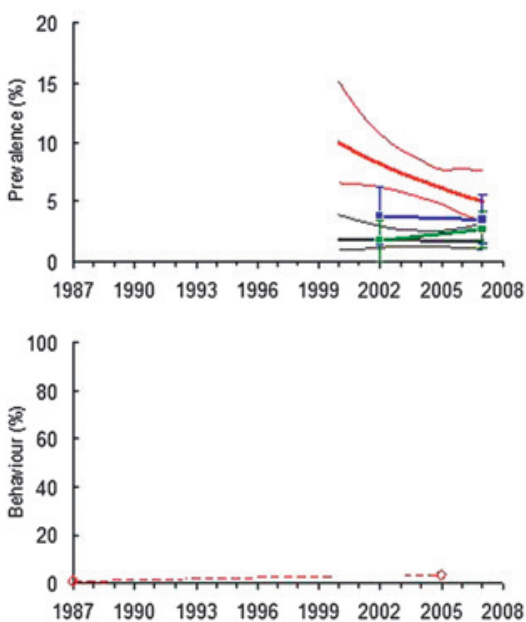

Rwanda
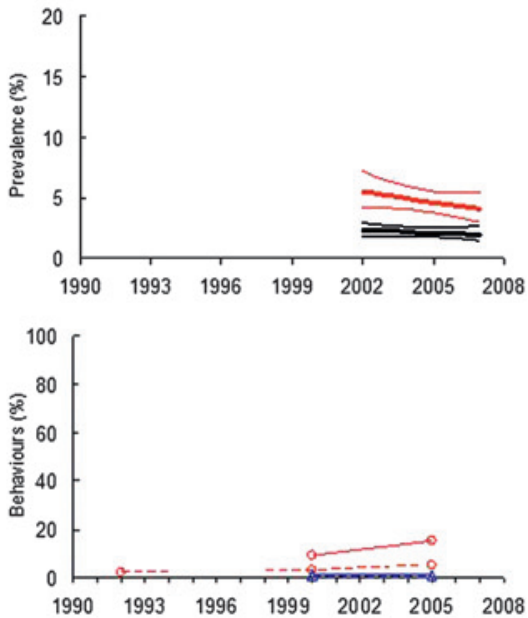

C

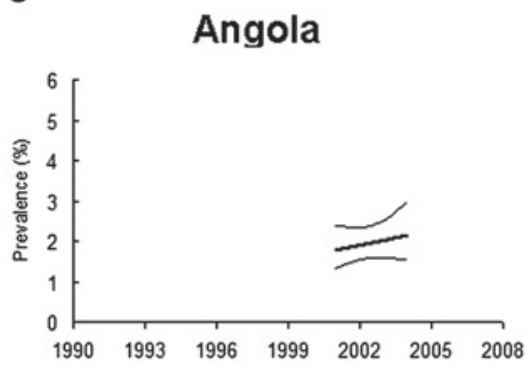

Eastern Africa

Ethiopia
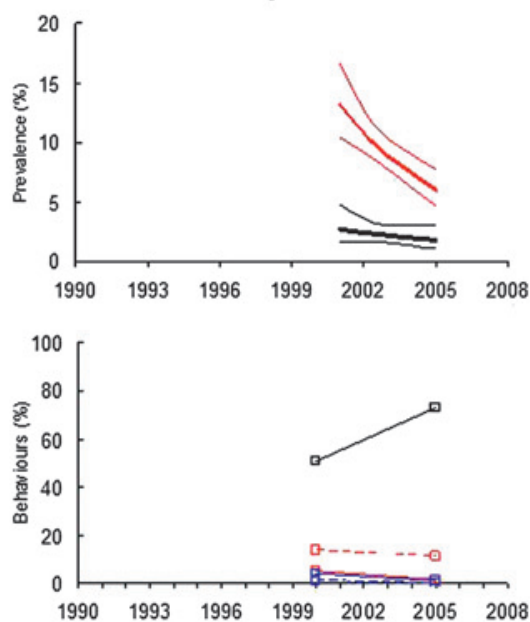

Uganda
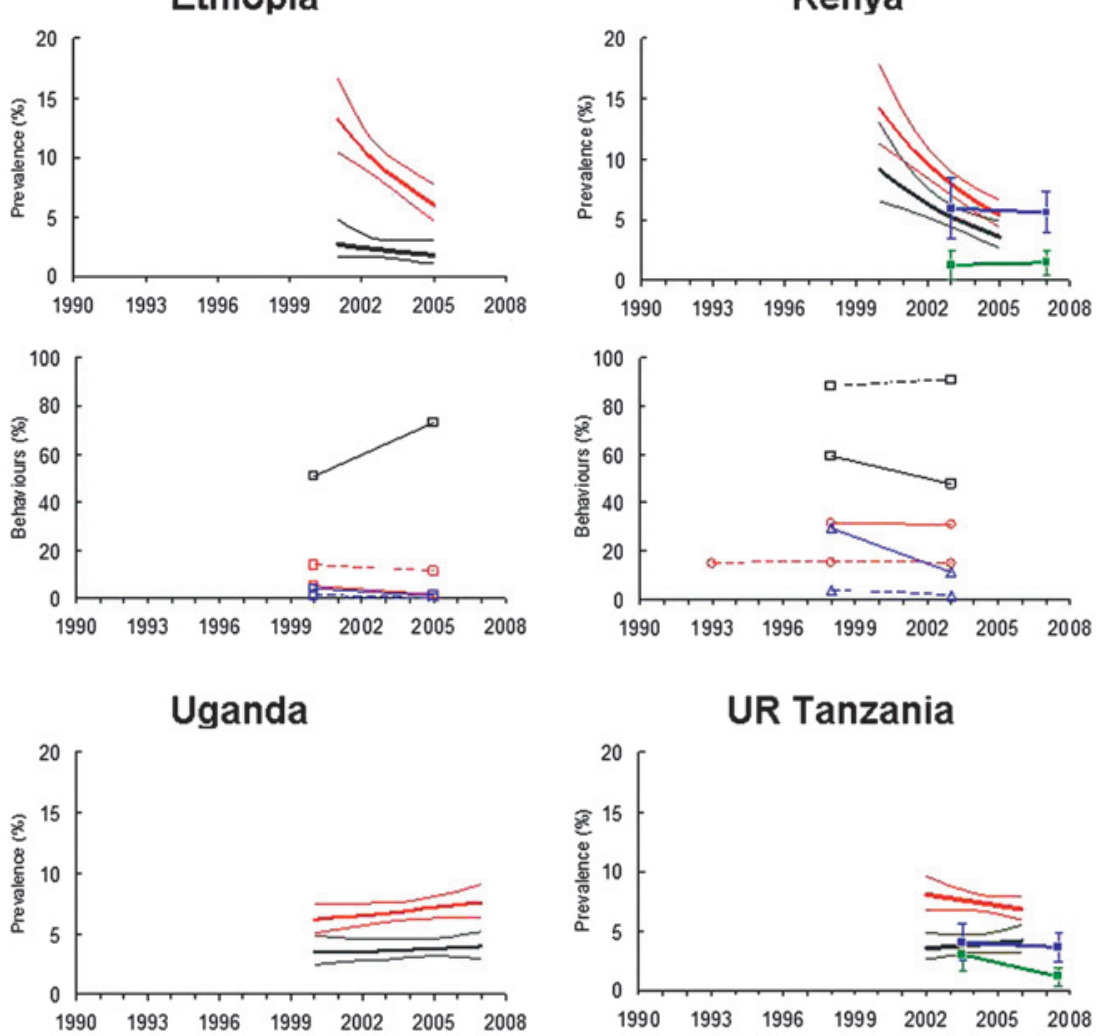

UR Tanzania
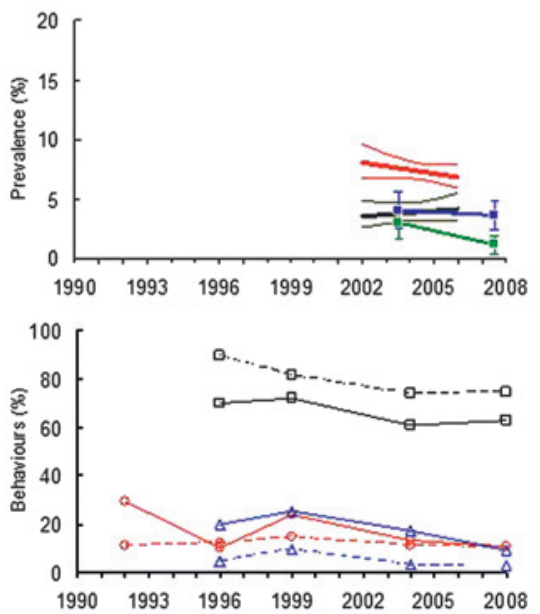

\section{Central Africa}

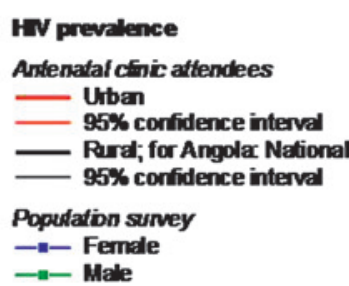

IN prevalence

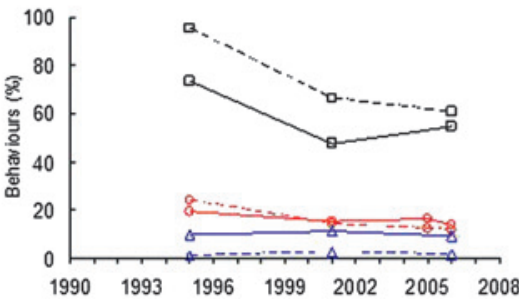

$\begin{array}{lllllll}1990 & 1993 & 1996 & 1999 & 2002 & 2005 & 2008\end{array}$

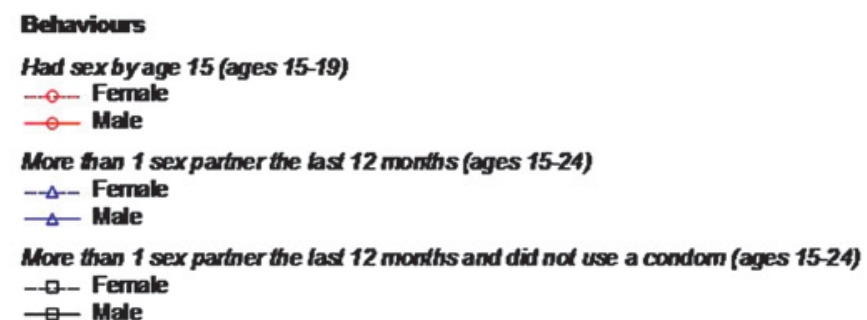

\section{Behaviours}

七- Male

Figure 1 (Continued). 
D

Côte d'Ivoire
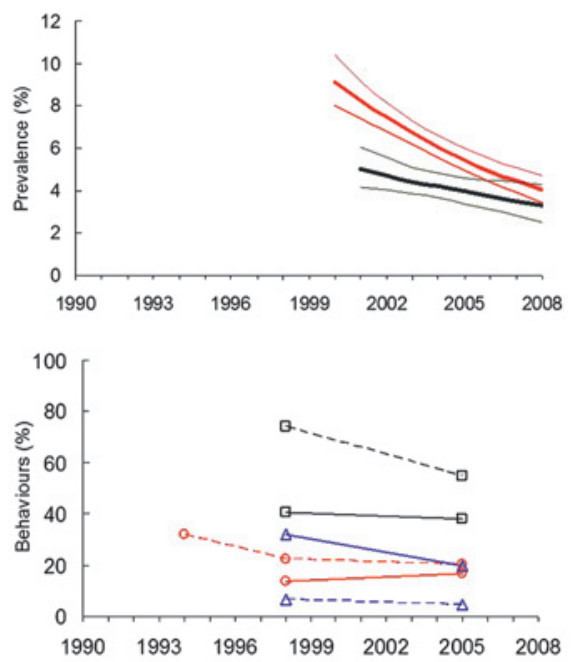

E

\section{Bahamas}

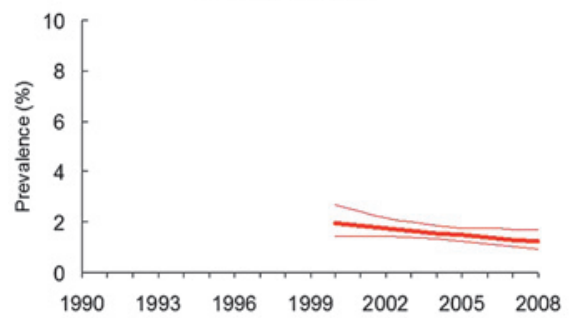

West Africa

Nigeria
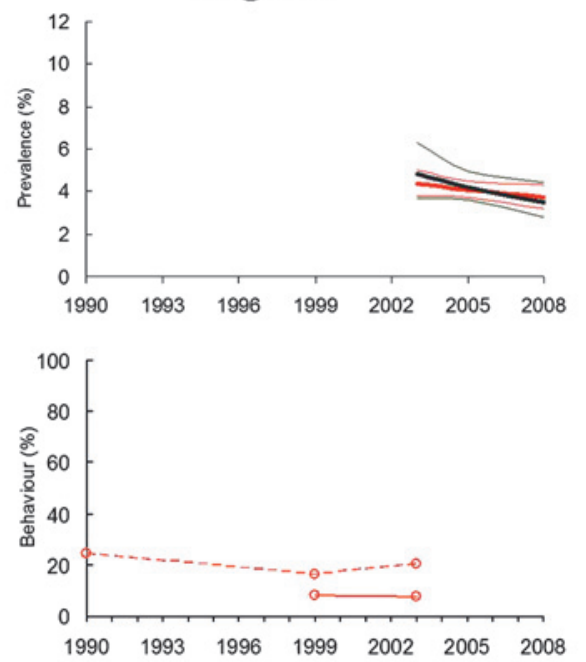

Caribbean

Haiti
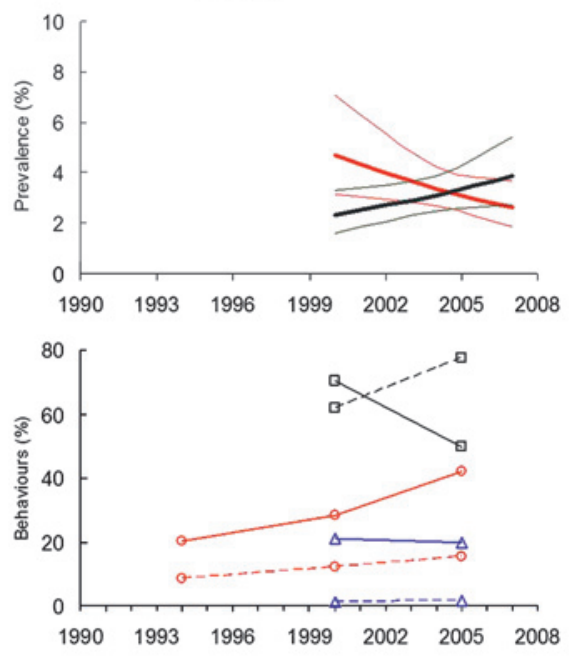

Togo

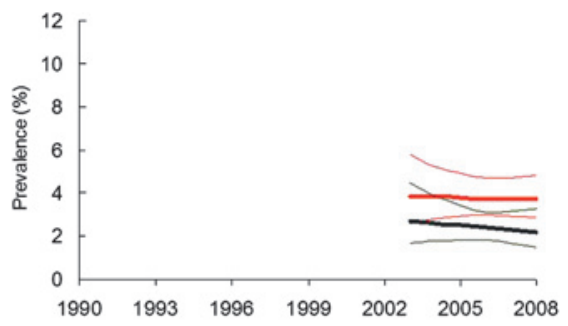

\section{Cameroon}

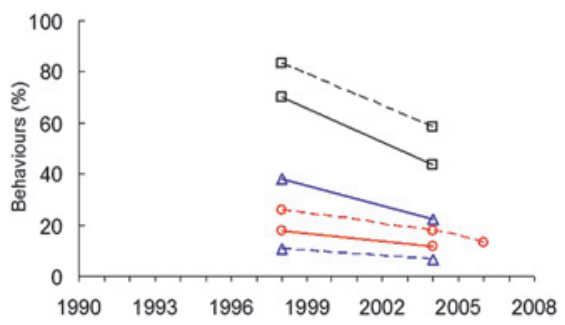

\section{HIV prevalence}

Antenatal clinic attendees - Urban

95\% confidence interval

Rural

95\% confidence interval

Population survey

- - Female

- - Male

\section{Behaviours}

Had sex by age 15 (ages 15-19)

-a- Female

- - Male

More than 1 sex partner the last 12 months (ages 15-24)

$-\rightarrow-$ Female

$\triangle$ Male

More than 1 sex partner the last 12 months and did not use a condom (ages 15-24) $-\rightarrow-$ Female $\rightarrow$ Male

Figure 1 (Continued).

available for a minimum of three points in time during the 2000-8 period. The analysis was conducted separately for urban and rural sites whenever data were available. For two countries (Angola and South Africa) the analysis was done at the national level only, whereas for Mozambique it was done for each of the three regions (south, central, north). For each country, the percentage change in fitted prevalence was calculated between the first and last year for which data were available. The slope of the curve was considered significantly different from zero for a $p$-value of less than 0.05 . Country data are shown for a selection of countries in the technical annexe and are available from the authors on request.

For countries that have conducted two or more national HIV prevalence surveys between 2000 and 2008, the HIV prevalence among 15-24-year-old men and women was taken from the published survey reports and compared between the different 
survey years. Prevalence surveys included AIDS indicator surveys (Botswana, Kenya and Tanzania; available at http:// www.measuredhs.com), demographic and health surveys (Kenya, Zambia and Zimbabwe; available at http://www. measuredhs.com), large national household surveys (Burundi, South Africa) ${ }^{15-19}$ and a national survey on HIV and sexual health among young adults in Zimbabwe in $2001 / 2{ }^{20} \chi^{2}$ Tests were performed to assess whether differences in prevalence were statistically significant at $p<0.05$.

\section{Behavioural data}

Three indicators on sexual behaviour recommended for monitoring and reporting of the 2001 UNGASS $^{14}$ were analysed to assess changes in behaviour over time. These indicators are: (1) the percentage of young people aged 15-19 years who reported having had sexual intercourse by the age of 15 years; (2) the percentage of young men and women aged 15-24 years who reported having had sexual intercourse with more than one partner in the past 12 months; (3) the percentage of those young men and women aged 15-24 years who had more than one partner in the past 12 months and reported having used a condom during the last sex act.

Data for the above indicators were obtained from behavioural surveys conducted between 1990 and 2008. The period for assessment of trends in behavioural indicators was longer than that for assessment of HIV prevalence trends as current changes in HIV prevalence might be associated with behaviour change some years earlier. To ensure consistency of the data collection

Table 2 Analysis of HIV prevalence data from young women aged 15-24 years attending ANC using sites that were consistently included in surveillance over time

\begin{tabular}{|c|c|c|c|c|c|c|c|c|}
\hline \multirow[b]{2}{*}{ Region } & \multirow[b]{2}{*}{ Country } & & \multicolumn{2}{|c|}{$\begin{array}{l}\text { Period of } \\
\text { assessment* }\end{array}$} & \multicolumn{2}{|c|}{$\begin{array}{l}\text { Predicted } \\
\text { prevalence } \dagger\end{array}$} & \multirow{2}{*}{$\begin{array}{l}\% \text { Change in predicted } \\
\text { prevalence from first to } \\
\text { last year of assessment } \\
\text { period }\end{array}$} & \multirow[b]{2}{*}{ p Value } \\
\hline & & & $\begin{array}{l}\text { First } \\
\text { year }\end{array}$ & $\begin{array}{l}\text { Last } \\
\text { year }\end{array}$ & $\begin{array}{l}\text { First } \\
\text { year }\end{array}$ & $\begin{array}{l}\text { Last } \\
\text { year }\end{array}$ & & \\
\hline \multirow[t]{12}{*}{ East Africa } & \multirow[t]{2}{*}{ Burundi } & Urban & 2000 & 2007 & 9.9 & 5.0 & 49.2 & 0.065 \\
\hline & & Rural & 2000 & 2007 & 1.8 & 1.7 & 5.2 & 0.928 \\
\hline & \multirow[t]{2}{*}{ Ethiopia } & Urban & 2001 & 2005 & 13.2 & 6.0 & 54.5 & $<0.001$ \\
\hline & & Rural & 2001 & 2005 & 2.7 & 1.7 & 35.0 & 0.347 \\
\hline & \multirow[t]{2}{*}{ Kenya } & Urban & 2000 & 2005 & 14.2 & 5.4 & 62.2 & $<0.001$ \\
\hline & & Rural & 2000 & 2005 & 9.2 & 3.6 & 61.0 & 0.001 \\
\hline & \multirow[t]{2}{*}{ Tanzania } & Urban & 2002 & 2006 & 8.0 & 6.8 & 15.5 & 0.204 \\
\hline & & Rural & 2002 & 2006 & 3.5 & 4.2 & -17.9 & 0.487 \\
\hline & \multirow[t]{2}{*}{ Rwanda } & Urban & 2002 & 2007 & 5.5 & 4.1 & 26.2 & 0.199 \\
\hline & & Rural & 2002 & 2007 & 2.3 & 1.9 & 14.2 & 0.517 \\
\hline & \multirow[t]{2}{*}{ Uganda } & Urban & 2000 & 2007 & 6.1 & 7.6 & -23.3 & 0.183 \\
\hline & & Rural & 2000 & 2007 & 3.4 & 3.9 & -15.7 & 0.581 \\
\hline \multirow{19}{*}{$\begin{array}{l}\text { Southern } \\
\text { Africa }\end{array}$} & \multirow{2}{*}{ Botswana } & Urban & 2001 & 2006 & 32.9 & 24.8 & 24.8 & 0.003 \\
\hline & & Rural & 2001 & 2006 & 33.6 & 23.6 & 29.9 & $<0.001$ \\
\hline & \multirow[t]{2}{*}{ Lesotho } & Urban & 2003 & 2007 & 25.8 & 24.7 & 4.0 & 0.704 \\
\hline & & Rural & 2003 & 2007 & 21.1 & 14.3 & 32.3 & 0.090 \\
\hline & \multirow[t]{2}{*}{ Malawi } & Urban & 1999 & 2007 & 27.6 & 12.2 & 55.8 & $<0.001$ \\
\hline & & Rural & 1999 & 2007 & 8.2 & 10.1 & -22.6 & 0.443 \\
\hline & \multirow[t]{3}{*}{ Mozambique } & South & 2001 & 2007 & 12.9 & 17.1 & -32.2 & 0.166 \\
\hline & & Central & 2001 & 2007 & 15.9 & 15.2 & 4.6 & 0.774 \\
\hline & & North & 2001 & 2007 & 7.3 & 8.1 & -10.9 & 0.588 \\
\hline & \multirow[t]{2}{*}{ Namibia } & Urban & 2002 & 2008 & 16.9 & 10.6 & 37.1 & 0.007 \\
\hline & & Rural & 2002 & 2008 & 16.4 & 8.5 & 48.0 & $<0.001$ \\
\hline & South Africa & National & 2000 & 2007 & 20.5 & 20.4 & 0.3 & 0.983 \\
\hline & \multirow{2}{*}{ Swaziland } & Urban & 2002 & 2008 & 40.8 & 33.9 & 16.9 & 0.058 \\
\hline & & Rural & 2002 & 2008 & 36.6 & 34.7 & 5.1 & 0.600 \\
\hline & \multirow[t]{2}{*}{ Zambia } & Urban & 2002 & 2006 & 24.5 & 23.2 & 5.6 & 0.545 \\
\hline & & Rural & 2002 & 2006 & 11.2 & 9.3 & 17.3 & 0.301 \\
\hline & \multirow[t]{3}{*}{ Zimbabwe } & Urban & 2000 & 2006 & 28.9 & 16.4 & 43.1 & $<0.001$ \\
\hline & & Rural & 2000 & 2006 & 23.4 & 15.9 & 31.7 & 0.044 \\
\hline & & Other & 2000 & 2006 & 31.9 & 20.2 & 36.8 & 0.001 \\
\hline $\begin{array}{l}\text { Central } \\
\text { Africa }\end{array}$ & Angola & National & 2004 & 2007 & 1.8 & 2.2 & -21.2 & 0.440 \\
\hline \multirow[t]{6}{*}{ West Africa } & Cote d'Ivoire & Urban & 2000 & 2008 & 9.1 & 4.9 & 56.0 & $<0.001$ \\
\hline & & Rural & 2001 & 2008 & 5.0 & 3.3 & 34.8 & 0.028 \\
\hline & Nigeria & Urban & 2003 & 2008 & 4.4 & 3.7 & 15.2 & 0.151 \\
\hline & & Rural & 2003 & 2008 & 4.8 & 3.5 & 27.4 & 0.110 \\
\hline & Togo & Urban & 2003 & 2008 & 3.8 & 3.7 & 3.9 & 0.872 \\
\hline & & Rural & 2003 & 2008 & 2.7 & 2.2 & 18.8 & 0.576 \\
\hline Caribbean & Bahamas & Urban & 2000 & 2008 & 2.0 & 1.2 & 37.1 & 0.090 \\
\hline & Haiti & Urban & 2000 & 2007 & 4.7 & 2.6 & 44.6 & 0.061 \\
\hline & & Rural & 2000 & 2007 & 2.3 & 3.8 & -67.2 & 0.080 \\
\hline
\end{tabular}


methodology and the definition of the indicators, only data from demographic and health surveys (available at http://www. measuredhs.com) or multiple indicator cluster surveys (available at http://www.unicef.org), or the repeated national populationbased surveys conducted by the Human Sciences Research Council in South Africa ${ }^{17-19}$ were used in this analysis.

For countries with more than one behavioural survey, the average annual rate of decline/increase was calculated for each behaviour indicator by country. The statistical significance of changes over time was assessed using a $\chi^{2}$ test of association for those countries where only two surveys had been conducted, or a $\chi^{2}$ test for trend for those countries where more than two surveys had been conducted during the time period of interest. A p-value of less than 0.05 was considered statistically significant.

\section{RESULTS}

\section{Available data}

Available data are summarised in table 1 . Thirty countries with estimated adult prevalence greater than $2 \%$ in 2007 were invited to contribute HIV prevalence data for 15-24-year-old pregnant women attending ANC, of which 26 responded positively. Five of the countries that responded either did not have the required site-specific data for young women (Cameroon and Djibouti) or did not have data for at least three points in time during the 2000-8 period (Central African Republic, Chad and Gabon) and were therefore not eligible for the regression analysis. Among the 21 eligible countries, the overall time period for which HIV prevalence data were available ranged from 9 years (eg, Bahamas, Malawi, Côte d'Ivoire) to 4 years (Angola). The number of times surveillance was done in a country over the 2000-8 period (yearly data points), varied from a minimum of three to a maximum of nine times. In addition, table 1 shows the variation between countries in the number of sites that were consistently included in surveillance efforts over time.

Seven countries (Botswana, Burundi, Kenya, South Africa, United Republic of Tanzania, Zambia and Zimbabwe) had repeated national HIV prevalence surveys for which HIV prevalence data were available on 15-24-year-old men and women. Repeat behavioural survey data were available to conduct trend analysis of the three behavioural indicators for 17, 14, and 12 countries, respectively (table 1 ). Information was available for all three indicators in 12 countries. In Rwanda, the sample sizes were too small to compare condom use among those who reported having had multiple sex partners in the past year. In South Africa, data were only available on the percentage of young people reported having had multiple sex partners, whereas in Mozambique trend data were only available on the percentage of young people reported to have had sex by the age of 15 years. In Burundi and the Central African Republic, additional multiple indicator cluster surveys allowed comparison of the percentage of young people reported to have had sex by age 15 years.

\section{HIV prevalence trends}

HIV prevalence trends among 15-24-year-old pregnant women showed a decline in either urban or rural areas in 17 of the 21 participating countries (figure 1, table 2). Thirteen countries showed a reduction in HIV prevalence of $25 \%$ or more between 2000 and 2008 in either urban or rural areas or both, with statistically significant results in Kenya between 2000 and 2005 (more than $60 \%$ change in both urban and rural areas, $\mathrm{p}<0.01$ ), urban Ethiopia between 2001 and 2005 (55\% change, $p<0.01)$, urban Malawi between 1999 and 2007 (56\% change, $\mathrm{p}<0.01$ ), Namibia between 2002 and 2008 (urban change 37\%, p $<0.01$; rural change $48 \%, \mathrm{p}<0.01$ ), Zimbabwe between 2000 and 2006 (urban change $43 \%, \mathrm{p}<0.01$; rural change $32 \%, \mathrm{p}<0.05)$, Botswana between 2001 and 2006 (urban change $25 \%, p<0.01$; rural change $30 \%, p<0.01$ ) and Côte d'Ivoire between 2000 and 2008 (urban change 56\%, $\mathrm{p}<0.01$; rural change $35 \%, \mathrm{p}<0.05$ ).

Of the seven countries with repeated HIV prevalence surveys, all except South Africa showed a decline in HIV prevalence among young women over time, whereas only four showed a decline among young men (table 3). In Botswana, Zambia and Zimbabwe, the prevalence decline among women was statistically significant (Botswana from 18.2\% in 2004 to $10.7 \%$ in 2008, p<0.0001; Zambia from $11.2 \%$ in 2002 to $8.5 \%$ in 2007 , $\mathrm{p}=0.018$; Zimbabwe from $17.4 \%$ in 2002 to $10.9 \%$ in 2006, $\mathrm{p}<0.001$ ), whereas in Tanzania and South Africa the decline among young men was statistically significant (Tanzania from $3 \%$ in 2003 to $1.1 \%$ in $2007, p<0.001$; South Africa from $6.1 \%$ in 2003 to $3.6 \%$ in $2008, p=0.005$ ). In most instances the significant reductions exceeded $25 \%$. In South Africa, the overall trend in prevalence observed among young women participating in national surveys between 2002 and 2008 was not statistically significant. However, prevalence during this period first increased from $12 \%$ in 2002 to $16.7 \%$ in 2005 , then declined to

Table 3 HIV prevalence among young men and women aged 15-24 years from repeat national population-based surveys

\begin{tabular}{|c|c|c|c|c|c|c|c|c|c|c|}
\hline \multirow[b]{2}{*}{ Country } & \multirow{2}{*}{$\begin{array}{l}\text { Year of } \\
\text { survey }\end{array}$} & \multirow[b]{2}{*}{ Type of survey } & \multicolumn{3}{|c|}{ Females $15-24$ years } & \multirow[b]{2}{*}{ p Value } & \multicolumn{3}{|c|}{ Males $15-24$ years } & \multirow[b]{2}{*}{ p Value } \\
\hline & & & n & Prevalence (\%) & SE & & $\mathrm{n}$ & Prevalence (\%) & SE & \\
\hline \multirow[t]{2}{*}{ Botswana } & 2004 & BAIS ॥ & 1593 & 18.2 & 1.93 & $<0.001$ & 1480 & 5.8 & 1.22 & 0.225 \\
\hline & 2008 & BAIS III & 1476 & 10.7 & 1.61 & & 1338 & 4.8 & 1.17 & \\
\hline Burundi & 2007 & Household & 1306 & 3.5 & 1.02 & & 1736 & 2.7 & 0.78 & \\
\hline \multirow[t]{2}{*}{ Kenya } & 2003 & DHS & 1369 & 5.9 & 1.27 & 0.681 & 1311 & 1.2 & 0.60 & 0.647 \\
\hline & 2007 & AIS & 2926 & 5.6 & 0.85 & & 2209 & 1.4 & 0.50 & \\
\hline South Africa & 2008 & HSRC & 1986 & 13.9 & 1.55 & & 1631 & 3.6 & 0.92 & \\
\hline \multirow[t]{2}{*}{ UR Tanzania } & 2003.5 & AIS & 2388 & 4 & 0.80 & 0.402 & 2084 & 3 & 0.75 & $<0.001$ \\
\hline & 2007.5 & AIS & 3286 & 3.6 & 0.65 & & 2940 & 1.1 & 0.38 & \\
\hline \multirow[t]{2}{*}{ Zambia } & 2002 & DHS & 940 & 11.2 & 2.06 & 0.018 & 675 & 3 & 1.31 & 0.125 \\
\hline & 2007 & DHS & 2225 & 8.5 & 1.18 & & 2027 & 4.3 & 0.90 & \\
\hline
\end{tabular}

AIS, AIDS indicator survey; BAIS, Botswana AIDS Indicator Survey; DHS, demographic and health survey; HSRC, Human Sciences Research Council. 
$13.9 \%$ in 2008, and could therefore suggest a decline in incidence as shown elsewhere. ${ }^{21}$

\section{Behavioural trends}

A reduction in the proportion of 15-19-year olds with early sexual debut was observed among women and men in 13/17 (statistically significant in eight) and 11/16 (statistically significant in seven) countries, respectively, as shown in table 4 and figure 1 . In four countries (Cameroon, Ethiopia, Malawi and Zambia), the decrease was significant in both women and men.

A reduction in the proportion of 15-24-year old with multiple partners in the past 12 months was found in 10/14 (significant in seven) and 13/14 (significant in 10) countries for women and men, respectively (table 5 , figure 1 ). In seven countries (Cameroon, Côte d'Ivoire, Ethiopia. Kenya, Tanzania, Zambia and Zimbabwe) there was a significant reduction in both men and women.

Table 4 Percentage of young people aged 15-19 years who reported having had sexual intercourse by the age of 15 years

\begin{tabular}{|c|c|c|c|c|c|c|c|c|c|}
\hline \multirow[b]{2}{*}{ Country } & \multirow[b]{2}{*}{$\begin{array}{l}\text { Year of } \\
\text { survey }\end{array}$} & \multicolumn{3}{|c|}{ Females } & \multirow[b]{2}{*}{ p Value } & \multicolumn{3}{|c|}{ Males } & \multirow[b]{2}{*}{ p Value } \\
\hline & & $\mathbf{n}$ & $\%$ & $\begin{array}{l}\text { Decline per } \\
\text { year }(\%)\end{array}$ & & $\mathrm{n}$ & $\%$ & $\begin{array}{l}\text { Decline per } \\
\text { year }(\%)\end{array}$ & \\
\hline \multirow[t]{2}{*}{ Burundi } & 1987 & 1000 & 0.7 & & & & & & \\
\hline & $2005^{*}$ & 2357 & 3.1 & -8.27 & $<0.001$ & & & & \\
\hline \multirow[t]{3}{*}{ Cameroon } & 1998 & 1282 & 26.0 & & & 539 & 17.8 & & \\
\hline & 2004 & 2685 & 18.0 & & & 1224 & 11.5 & 7.28 & 0.0004 \\
\hline & $2006^{*}$ & 2016 & 13.4 & 7.79 & $<0.001$ & & & & \\
\hline \multirow{2}{*}{$\begin{array}{l}\text { Central African } \\
\text { Republic }\end{array}$} & $1994^{*}$ & 1288 & 24.6 & & & 321 & 16.0 & & \\
\hline & $2006^{*}$ & 2572 & 27.0 & -0.78 & 0.114 & 860 & 11.7 & 2.61 & 0.056 \\
\hline \multirow[t]{2}{*}{ Chad } & 1997 & 1716 & 21.9 & & & 490 & 7.9 & & \\
\hline & 2004 & 1361 & 19.0 & 2.03 & 0.045 & 406 & 10.7 & -4.33 & 0.174 \\
\hline \multirow[t]{3}{*}{ Cote D'Ivoire } & 1994 & 1961 & 31.9 & & & & & & \\
\hline & 1998 & 775 & 22.1 & & & 180 & 13.8 & & \\
\hline & 2005 & 1232 & 20.4 & 3.73 & $<0.001$ & 898 & 16.7 & -2.72 & 0.349 \\
\hline \multirow[t]{2}{*}{ Ethiopia } & 2000 & 3710 & 13.5 & & & 600 & 5.1 & & \\
\hline & 2005 & 3266 & 11.1 & 3.91 & 0.002 & 1335 & 1.7 & 21.97 & $<0.001$ \\
\hline \multirow[t]{3}{*}{ Haiti } & 1994 & 1290 & 8.4 & & & 350 & 20.1 & & \\
\hline & 2000 & 2342 & 12.0 & & & 768 & 28.3 & & \\
\hline & 2005 & 2701 & 15.3 & -5.47 & $<0.001$ & 1211 & 41.9 & -6.65 & $<0.001$ \\
\hline \multirow[t]{3}{*}{ Kenya } & 1993 & 1754 & 14.9 & & & & & & \\
\hline & 1998 & 1851 & 15.0 & & & 811 & 31.7 & & \\
\hline & 2003 & 1856 & 14.5 & 0.27 & 0.739 & 856 & 30.9 & 0.51 & 0.747 \\
\hline \multirow[t]{3}{*}{ Malawi } & 2000 & 2867 & 16.5 & & & 660 & 29.1 & & \\
\hline & 2004 & 2392 & 14.1 & & & 650 & 18.0 & 12.01 & $<0.001$ \\
\hline & $2006^{*}$ & 5196 & 13.9 & 3.01 & 0.001 & & & & \\
\hline \multirow[t]{2}{*}{ Mozambique } & 1997 & 1836 & 28.6 & & & 382 & 23.5 & & \\
\hline & 2003 & 2454 & 27.7 & 0.35 & 0.666 & 673 & 31.1 & -4.62 & 0.009 \\
\hline \multirow[t]{3}{*}{ Namibia } & 1992 & 1259 & 7.7 & & & & & & \\
\hline & 2000 & 1499 & 9.8 & & & 694 & 31.3 & & \\
\hline & 2006 & 2246 & 7.4 & 0.11 & 0.589 & 910 & 19.2 & 8.15 & $<0.001$ \\
\hline \multirow[t]{3}{*}{ Nigeria } & 1990 & 1612 & 24.4 & & & & & & \\
\hline & 1999 & 1775 & 16.2 & & & 511 & 8.3 & & \\
\hline & 2003 & 1716 & 20.3 & 1.90 & $<0.001$ & 453 & 7.9 & 1.23 & 0.877 \\
\hline Rwanda & 1992 & 1464 & 2.1 & & & & & & \\
\hline & 2000 & 2617 & 3.0 & & & 762 & 9.3 & & \\
\hline & 2005 & 2585 & 5.2 & -6.7 & $<0.001$ & 1102 & 15.3 & -9.96 & $<0.001$ \\
\hline UR Tanzania & 1992 & 2183 & 11.4 & & & 499 & 29.6 & & \\
\hline & 1996 & 1732 & 12.3 & & & 488 & 10.4 & & \\
\hline & 1999 & 909 & 14.5 & & & 790 & 23.9 & & \\
\hline & 2004 & 2245 & 11.4 & & & 637 & 13.0 & & \\
\hline & 2007.5 & 1984 & 10.7 & 0.62 & 0.285 & 1768 & 10.8 & 4.83 & $<0.001$ \\
\hline Uganda & 1995 & 1606 & 23.8 & & & 387 & 19.2 & & \\
\hline & 2000.5 & 1615 & 14.2 & & & 441 & 15.5 & & \\
\hline & 2004.5 & 2186 & 12.2 & & & 2069 & 16.3 & & \\
\hline & 2006 & 1936 & 11.8 & 6.48 & $<0.001$ & 595 & 13.9 & 2.39 & 0.096 \\
\hline Zambia & 1992 & 1984 & 19.4 & & & & & & \\
\hline & 1996 & 2003 & 21.7 & & & 460 & 39.3 & & \\
\hline & 2001.5 & 1811 & 17.5 & & & 459 & 27.2 & & \\
\hline & 2007 & 1574 & 12.3 & 3.30 & $<0.001$ & 1416 & 16.2 & 8.06 & $<0.001$ \\
\hline Zimbabwe & 1994 & 1472 & 5.2 & & & 604 & 7.9 & & \\
\hline & 1999 & 1447 & 3.2 & & & 713 & 6.3 & & \\
\hline & 2005.5 & 2152 & 4.9 & 0.17 & 0.994 & 1899 & 5.2 & 3.60 & 0.013 \\
\hline
\end{tabular}

${ }^{*}$ Results from multiple indicator cluster survey. 
Finally, a reduced proportion of young people not using condoms was seen in six out of 11 (significant in six) and 11/12 (significant in five) countries for women and men, respectively (table 6, and figure 1). Significant increases in condom use in both sexes occurred in Cameroon, Tanzania and Uganda.

\section{Association of prevalence and behavioural trends}

Of the 11 countries that had trends established for both HIV prevalence and behaviour (for at least two indicators), eight countries showed a significant HIV prevalence reduction whereas three did not. All eight of the countries with a decline in prevalence also had favourable trends in behaviours (defined as a significant trend in either men or women for at least two of the three behavioural indicators) that overlapped or started before the period of prevalence decline: Côte d'Ivoire, Ethiopia, Kenya, Malawi, Namibia, Tanzania, Zambia and Zimbabwe. Of the three countries that did not have a significant decline in HIV prevalence, Uganda showed favourable trends in behaviours whereas Haiti and Rwanda did not.

\section{DISCUSSION}

The UNGASS target for a significant reduction in HIV prevalence of $25 \%$ or more among 15-24 year-old ANC attendees by 2005 was reached by Botswana, Côte d'Ivoire (urban areas),
Ethiopia (urban areas), Kenya, Malawi (urban areas) and Zimbabwe, as well as by South African men included in the 2002 and 2005 surveys. By 2008, Namibia and Côte d'Ivoire (rural areas) also showed a significant reduction in HIV prevalence of over $25 \%$ among ANC attendees, as did Tanzanian men and Zambian women included in national surveys. Seven other countries (Burundi (urban areas), Lesotho (rural areas), Nigeria (rural areas), Rwanda, Swaziland (urban areas), Bahamas and Haiti (urban areas)) seem to be on track to reach the UNGASS target of a significant $25 \%$ reduction by 2010 . Two countries seem unlikely to achieve a $25 \%$ reduction in prevalence by 2010 as HIV prevalence did not show a decline during the study period (Angola, Mozambique). In addition, Uganda, after significant declines in prevalence in the 1990s, showed an increase, although not statistically significant, in HIV prevalence among young women attending ANC between 2000 and 2007. Finally, five of the 26 countries that responded to the invitation to participate in this study currently do not have enough data to allow an assessment of the HIV prevalence trends.

Mathematical modelling suggests that trends in HIV prevalence in 15-24-year-old ANC attendees approximate trends in this age group in the general population, although the former may be slow to reflect declines in the latter when there is a concomitant increase in age at first sex. ${ }^{11} \mathrm{~A}$ recent study in

Table 5 Percentage of young men and women aged 15-24 years who reported having had sexual intercourse with more than one partner in the past 12 months

\begin{tabular}{|c|c|c|c|c|c|c|c|c|c|}
\hline \multirow[b]{2}{*}{ Country } & \multirow[b]{2}{*}{$\begin{array}{l}\text { Year of } \\
\text { survey }\end{array}$} & \multicolumn{3}{|c|}{ Females } & \multirow[b]{2}{*}{ p Value } & \multicolumn{3}{|c|}{ Males } & \multirow[b]{2}{*}{ p Value } \\
\hline & & $\mathrm{n}$ & $\%$ & $\begin{array}{l}\text { Decline per } \\
\text { year }(\%)\end{array}$ & & $\mathrm{n}$ & $\%$ & $\begin{array}{l}\text { Decline per } \\
\text { year }(\%)\end{array}$ & \\
\hline \multirow[t]{2}{*}{ Cameroon } & 1998 & 2409 & 10.6 & & & 1067 & 38.3 & & \\
\hline & 2004 & 4937 & 6.6 & 7.90 & $<0.001$ & 2177 & 22.4 & 8.94 & $<0.001$ \\
\hline \multirow[t]{2}{*}{ Chad } & 1997 & 3084 & 1.2 & & & 863 & 22.9 & & \\
\hline & 2004 & 2432 & 1.0 & 2.60 & 0.453 & 673 & 12.0 & 9.23 & $<0.001$ \\
\hline \multirow[t]{2}{*}{ Cote D'Ivoire } & 1998 & 1353 & 6.7 & & & 338 & 32.1 & & \\
\hline & 2005 & 2360 & 4.5 & 5.69 & 0.003 & 1836 & 19.7 & 6.97 & $<0.001$ \\
\hline \multirow[t]{2}{*}{ Ethiopia } & 2000 & 6570 & 1.1 & & & 1007 & 4.3 & & \\
\hline & 2005 & 5813 & 0.1 & 47.96 & $<0.001$ & 2399 & 0.9 & 31.28 & $<0.001$ \\
\hline \multirow[t]{2}{*}{ Haiti } & 2000 & 4260 & 1.2 & & & 1280 & 21.2 & & \\
\hline & 2005 & 4704 & 1.5 & -4.46 & 0.203 & 2104 & 19.8 & 1.37 & 0.343 \\
\hline \multirow[t]{2}{*}{ Kenya } & 1998 & 3399 & 3.4 & & & 1400 & 29.5 & & \\
\hline & 2003 & 3547 & 1.6 & 15.08 & $<0.001$ & 1537 & 11.3 & 19.19 & $<0.001$ \\
\hline \multirow[t]{2}{*}{ Malawi } & 2000 & 5825 & 1.0 & & & 1259 & 11.8 & & \\
\hline & 2004 & 5262 & 1.1 & -2.38 & 0.583 & 1237 & 7.0 & 13.05 & $<0.001$ \\
\hline \multirow[t]{2}{*}{ Namibia } & 2000 & 2838 & 2.3 & & & 1304 & 14.8 & & \\
\hline & 2006 & 4101 & 2.2 & 0.74 & 0.791 & 1661 & 11.1 & 4.79 & 0.0025 \\
\hline \multirow[t]{2}{*}{ Rwanda } & 2000 & 4524 & 0.3 & & & 1195 & 1.2 & & \\
\hline & 2005 & 4938 & 0.3 & 0.0 & 0.960 & 2048 & 1.0 & 3.65 & 0.599 \\
\hline \multirow[t]{3}{*}{ South Africa } & 2002 & 634 & 8.8 & & & 517 & 23.0 & & \\
\hline & 2005 & 1397 & 6.0 & & & 972 & 27.2 & & \\
\hline & 2008 & NA & 6.0 & 6.4 & $\mathrm{NS}^{*}$ & NA & 30.8 & -4.9 & $\mathrm{NS}^{*}$ \\
\hline \multirow[t]{4}{*}{ Tanzania } & 1996 & 3408 & 4.7 & & & 859 & 19.8 & & \\
\hline & 1999 & 1720 & 9.8 & & & 1330 & 25.2 & & \\
\hline & 2004 & 4252 & 3.1 & & & 1130 & 17.2 & & \\
\hline & 2007.5 & 3730 & 2.5 & 8.42 & $<0.001$ & 2196 & 9.3 & 6.87 & $<0.001$ \\
\hline \multirow[t]{3}{*}{ Uganda } & 1995 & 3162 & 1.1 & & & 754 & 9.7 & & \\
\hline & 2000.5 & 3119 & 2.3 & & & 762 & 11.1 & & \\
\hline & 2006 & 3646 & 1.7 & -3.96 & 0.078 & 996 & 9.3 & 0.38 & 0.738 \\
\hline \multirow[t]{3}{*}{ Zambia } & 1996 & 3834 & 4.6 & & & 863 & 31.8 & & \\
\hline & 2002 & 3476 & 2.4 & & & 804 & 17.6 & & \\
\hline & 2007 & 2944 & 1.5 & 10.21 & $<0.001$ & 2482 & 8.8 & 11.62 & $<0.001$ \\
\hline \multirow[t]{2}{*}{ Zimbabwe } & 1999 & 2741 & 1.8 & & & 1219 & 10.8 & & \\
\hline & 2005.5 & 4104 & 0.9 & 10.5 & 0.001 & 3358 & 7.1 & 6.45 & $<0.001$ \\
\hline
\end{tabular}

*Denominators not available. Significant levels as reported in 2008 Human Sciences Research Council survey report. 
Table 6 Percentage of young people aged 15-24 years who had more than one partner in the past 12 months and reported having used a condom during the last sex act

\begin{tabular}{|c|c|c|c|c|c|c|c|c|c|}
\hline \multirow[b]{2}{*}{ Country } & \multirow[b]{2}{*}{$\begin{array}{l}\text { Year of } \\
\text { survey }\end{array}$} & \multicolumn{3}{|c|}{ Females } & \multirow[b]{2}{*}{ p Value } & \multicolumn{3}{|c|}{ Males } & \multirow[b]{2}{*}{ p Value } \\
\hline & & $\mathbf{n}$ & $\%$ & $\begin{array}{l}\text { Decline per } \\
\text { year }(\%)\end{array}$ & & $\mathbf{n}$ & $\%$ & $\begin{array}{l}\text { Decline per } \\
\text { year }(\%)\end{array}$ & \\
\hline \multirow[t]{2}{*}{ Cameroon } & 1998 & 255 & 17 & & & 408 & 30 & & \\
\hline & 2004 & 328 & 41.6 & 14.91 & $<0.001$ & 489 & 56.3 & 10.49 & $<0.001$ \\
\hline \multirow[t]{2}{*}{ Chad } & 1997 & 36 & 17.4 & & & 197 & 21.8 & & \\
\hline & 2004 & 50 & 9.1 & -9.26 & 0.334 & 163 & 26.3 & 2.68 & 0.313 \\
\hline \multirow[t]{2}{*}{ Cote D'Ivoire } & 1998 & 91 & 25.8 & & & 109 & 59.2 & & \\
\hline & 2005 & 106 & 45.1 & 7.98 & 0.004 & 361 & 61.8 & 0.61 & 0.638 \\
\hline \multirow[t]{2}{*}{ Ethiopia } & 2000 & 74 & 18 & & & 44 & 49.3 & & \\
\hline & 2005 & 6 & & & & 22 & 27 & -12.04 & 0.078 \\
\hline \multirow[t]{2}{*}{ Haiti } & 2000 & 51 & 38 & & & 271 & 29.7 & & \\
\hline & 2005 & 70 & 22.6 & -10.39 & 0.072 & 418 & 50.5 & 10.62 & $<0.001$ \\
\hline \multirow[t]{2}{*}{ Kenya } & 1998 & 117 & 11.9 & & & 413 & 40.6 & & \\
\hline & 2003 & 57 & 9.1 & -5.37 & 0.526 & 174 & 52.1 & 4.99 & 0.009 \\
\hline \multirow[t]{2}{*}{ Malawi } & 2000 & 60 & 20.3 & & & 148 & 26.8 & & \\
\hline & 2004 & 60 & 19.9 & -0.50 & 1 & 87 & 34.5 & 6.31 & 0.215 \\
\hline \multirow[t]{2}{*}{ Namibia } & 2000 & 66 & 57.4 & & & 192 & 73.8 & & \\
\hline & 2006 & 91 & 73.7 & 4.17 & 0.035 & 184 & 82.2 & 1.80 & 0.058 \\
\hline \multirow[t]{4}{*}{ Tanzania } & 1996 & 159 & 10 & & & 170 & 29.9 & & \\
\hline & 1999 & 168 & 18.2 & & & 335 & 28.1 & & \\
\hline & 2004 & 130 & 25.8 & & & 195 & 39.2 & & \\
\hline & 2007.5 & 93 & 25.4 & 7.82 & $<0.001$ & 272 & 36.9 & 2.60 & 0.012 \\
\hline \multirow[t]{3}{*}{ Uganda } & 1995 & 35 & 4.5 & & & 73 & 26.6 & & \\
\hline & 2000.5 & 53 & 33.8 & & & 85 & 52.8 & & \\
\hline & 2006 & 63 & 39.4 & 19.72 & 0.001 & 93 & 45.2 & 4.82 & 0.022 \\
\hline \multirow[t]{3}{*}{ Zambia } & 1996 & 176 & 23.2 & & & 274 & 34.7 & & \\
\hline & 2001 & 85 & 25.3 & & & 141 & 39.1 & & \\
\hline & 2007 & 43 & 41.5 & 5.38 & 0.026 & 218 & 43.1 & 1.96 & 0.056 \\
\hline \multirow[t]{2}{*}{ Zimbabwe } & 1999 & 50 & 40.2 & & & 132 & 58.1 & & \\
\hline & 2005.5 & 37 & 37.9 & -0.91 & 0.838 & 237 & 59.4 & 0.34 & 0.782 \\
\hline
\end{tabular}

Manicaland, Zimbabwe (unpublished data), provides the first empirical evidence corroborating this relationship. Modelling work also indicates that trends in HIV prevalence in 15-24-year olds can approximate trends in HIV incidence in the same age group. ${ }^{11}$ If so, the declines in HIV prevalence in ANC attendees observed in this study may reflect declines in HIV incidence in the general community. In the current study, Botswana and Zimbabwe show significant $(>25 \%)$ declines in HIV prevalence among women in both ANC surveillance and HIV prevalence surveys. In Zimbabwe, the downward trend in prevalence in young people has also been observed in a cohort study in Manicaland province and modelling of national prevalence data suggests that there have been important reductions in incidence during the early part of the current decade. ${ }^{22} 23$ In Botswana, a decline in prevalence among young women attending ANC was recently also reported elsewhere, ${ }^{24}$ but unfortunately Botswana does not have the benefit of an independent community-based cohort study. Other countries show significant declines in only one source of prevalence data, suggesting that infection rates may have been decreasing less strongly. In some instances, declines were observed only among one of the sexes or only in urban or rural areas. In Zambia and Tanzania, independent application of a mathematical model to HIV prevalence data from repeat national surveys also showed significant declines in incidence among women and men, respectively. ${ }^{25}$

While the restriction of the prevalence analysis to young people aged 15-24 years allows the interpretation of HIV prevalence trends being parallel to trends in incidence in this age group, the same restriction prevents any inference about incidence trends in other age groups. Data from several community- based studies in sub-Saharan Africa grouped in the ALPHA network suggest that recent patterns in HIV incidence among older people may be different from those among young people. ${ }^{26}$ Neither can HIV prevalence data among 15-24-year olds inform trends in HIV incidence among children, although independent analyses indicate that incidence among children has also been declining in recent years, ${ }^{2}$ mainly as a result of increased access to prevention of mother-to-child-transmission services. It is possible that a small percentage of children infected with HIV through mother-to-child transmission survive into their teens ${ }^{27}$ and become part of the HIV prevalence among 15-24year olds. However, the scale-up of prevention of motherto-child-transmission programmes is too recent ${ }^{1}$ to have contributed to a decrease in prevalence among 15-24-year olds during 2000-8.

Declines in HIV incidence can occur as part of the natural course of an HIV epidemic. Individuals with the highest risk behaviour in a population are usually infected rapidly during the early years of an epidemic. Subsequently, HIV incidence falls because those who have not been infected previously typically have relatively less risky behaviour. ${ }^{28} 29$ By focussing the current HIV prevalence analysis on 15-24-year olds and on the period 2000-8, which for most countries is at least a decade after the start of the epidemic, these natural history effects should largely have been avoided-ie, because those aged 15-24 years during 2000-8 were from a different birth cohort to those aged 15-24 years during the first decade of the epidemic. The HIV incidence declines implied by the reductions in HIV prevalence among 15-24-year olds recorded here are unlikely to be due to the natural history of the epidemic. 
The current analysis has focused on comparable behavioural indicators by restricting the analysis to data of standardised surveys, which are believed to allow a reliable assessment of trends in behaviour. ${ }^{30}$ Behavioural indicators can provide corroboration of changes in HIV incidence and assist in attributing changes to particular aspects of risk. ${ }^{31} 32$ Because of data limitations and the analytical approach, the current analysis cannot establish a causal association between changes in sexual behaviour and trends in HIV prevalence. However, it is encouraging that in the current analysis, most countries with HIV prevalence declines also show positive changes in sexual behaviour. Data collected on sexual behaviour over time may be subject to reporting bias, including social desirability bias, as prevention programmes can change the social norms regarding sexual behaviour. ${ }^{33}$ In addition, where there is mixing across age groups, behaviour changes in older people, particularly men, could cause reductions in prevalence in young people. The extent to which changes in HIV prevalence have been brought about by behavioural change programmes is beyond the scope of this paper, but needs to be investigated through further in-depth research and modelling, as has been done for Zimbabwe. ${ }^{23} 34$

In conclusion, this multicountry analysis of data from the 30 countries most affected by the AIDS epidemic reveals several important findings. First, of the 21 countries that have data to assess national trends in HIV prevalence among 15-24-year olds in recent years, the majority show declines in HIV prevalence, and in 10 countries statistically significant declines of more than $25 \%$ have occurred. Second, the declines in HIV prevalence are likely to be the result of declines in HIV incidence. Third, in most countries with prevalence declines, declines in risky sexual behaviours were also observed. Fourth, looking towards the 2010 UNGASS targets, there is a need to strengthen programmes to monitor trends in HIV prevalence, incidence and sexual behaviours, both in countries that have solid surveillance systems, and more urgently in countries that currently have insufficient data. All countries included in this analysis should consider conducting national surveys that measure both HIV prevalence and sexual behaviours at regular time intervals (eg, every 4 or 5 years). ${ }^{35}$ Finally, country-based evaluations should be conducted, drawing on an even larger set of quantitative and qualitative data sources to corroborate the trends found in this analysis and to study the relation between programmatic efforts and the observed behavioural and epidemiological changes.

\section{Key messages}

- HIV prevalence among young people aged 15-24 years declined significantly between 2000 and 2008 in 10 of 21 high burden countries.

- Changes towards less risky sexual behaviour have been observed among young men and women in the majority of countries included in this analysis.

- In the majority of countries with significant declines in HIV prevalence, significant changes were also observed in sexual behaviour in either men or women.

- Programmes to monitor trends in HIV prevalence, incidence and sexual behaviour should be strengthened.

- More data and further analysis are needed to understand the associations between prevention efforts, behavioural changes and changes in the prevalence and incidence of HIV.
Acknowledgements E Fadriquela (UNAIDS Geneva); M Gomes (Angola); F Gomez (Botswana); A Bamba-Louguet (Central African Republic); PE Ehounoud, LR Lobognon (Côte d'Ivoire); I Mohammed (Djibouti): C Fontaine (Ethiopia); B Olivia, R Nze Eyo'o (Gabon); E Louissaint, E Pierre, S Morisseau, C Desforges, F Carl, C Alzuphar, LM Boulous (Haiti); G Haile (Kenya); P Chikukwa (Malawi); M Mahy, M Oditt (Namibia); H Damisoni, J Sagbohan (Nigeria); E Pegurri (Rwanda); H Damisoni (South Africa); K Takpa (Togo); W Kirungi (Uganda); M Kibona, F Macha, J Nankinga, A Gavyole, A Chaddy (UR Tanzania); E Sattin (Zambia).

\section{Competing interests None.}

Contributors EG, PDG and RL wrote the first draft of the paper. BB provided data on sexual behaviour collected from national population based surveys. Country collaborators provided country-specific data on HIV prevalence and contributed to the country-specific analysis of trend data. EG performed the final statistical analysis.

E Fadriquela assisted with the production of Figure 1. All authors contributed to the final draft of the paper.

Provenance and peer review Not commissioned; externally peer reviewed.

\section{REFERENCES}

1. WHO/UNAIDS/UNICEF. Towards universal access. Scaling up priority HIVIAIDS interventions in the health sector. Progress report 2009. Geneva, Switzerland: WHO, 2009.

2. UNAIDS. 2008 Report on the global AIDS epidemic. Geneva: UNAIDS, 2008. http:// www.unaids.org (accessed 4 Nov 2010).

3. Hallett T, Zaba B, Todd J, et al. Estimating incidence from prevalence in generalised HIV epidemics: methods and validation. PLoS Med 2008;5:e80.

4. Gregson S, Donnelly CA, Parker CG, et al. Demographic approaches to the estimation of incidence of HIV-1 infection among adults from age-specific prevalence data in stable endemic conditions. AIDS 1996;10:1689-97.

5. Williams B, Gouws E, Wilkinson D, et al. Estimating HIV incidence rates from age prevalence data in epidemic situations. Stat Med 2001;20:2003-16.

6. Brown T, Salomon JA, Alkema L, et al. Progress and challenges in modelling country-level HIV/AIDS epidemics: the UNAIDS Estimation and Projection Package 2007. Sex Transm Infect 2008;84(Suppl 1):i5-10.

7. Stover J, Johnson P, Zaba B, et al. The Spectrum projection package: improvements in estimating mortality, ART needs, PMTCT impact and uncertainty bounds. Sex Transm Infect 2008;84(Suppl 1):i24-30.

8. Parekh BS, McDougal JS. Application of laboratory methods for estimation of HIV-1 incidence. Indian J Med Res 2005;121:510-18.

9. Janssen RS, Satten GA, Stramer SL, et al. New testing strategy to detect early HIV-1 infection for use in incidence estimates and for clinical and prevention purposes. JAMA 1998;280:42-8.

10. WHO. WHO Technical HIV Incidence Assay Working Group. http://www.who.int/ diagnostics laboratory/links/hiv incidence assay/en/index1.html laccessed 18 0ct 2009).

11. Zaba B, Boerma T, White R. Monitoring the AIDS epidemic using HIV prevalence data among young women attending antenatal clinics: prospects and problems. AIDS 2000;14:1633-45.

12. Ghys PD, Kufa E, George MV. Measuring trends in prevalence and incidence of HIV infection in countries with generalised epidemics. Sex Transm Infect 2006;82(Suppl 1):i52-6

13. United Nations. Declaration of Commitment on HIVIAIDS. New York: United Nations, 2001.

14. UNAIDS. Monitoring the Declaration of Commitment on HIVIAIDS: guidelines on construction of core indicators: 2008 reporting. Geneva, Switzerland: UNAIDS, 2008

15. Centre de Formation et de Recherche en Médecine et Maladies Infectieuses (CEFORMI). Enquete combinee de surveillance des comportements face au VIH/ SIDA/IST et d'estimation de la seroprevalence du VIH/SIDA au Burundi. Burundi: CEFORMI/IMEA, 2008.

16. Etude réalisée par le Centre de Formation et de Recherche en Médecine et Maladies Infectieuses (CEFORMI). Enquete nationale de seroprevalence de l'infection par le VIH au Burundi. Bujumbura: Ministère de la Sante Publique, Ministère à la Présidence Chargé de la Lutte contre le Sida, Banque Mondiale 2002.

17. Shisana 0, Simbayi L. Nelson Mandela/HSRC study of HIVIAIDS: South African national HIV prevalence, behavioural risks and mass media household survey 2002 Cape Town, South Africa: HSRC, 2003.

18. Shisana 0, Rehle T, Simbayi LC, et al. South African national HIV prevalence, HIV incidence, behaviour and communication survey, 2005. Cape Town, South Africa: HSRC Press, 2005.

19. Shisana 0, Rehle T, Simbayi LC, et al. South African national HIV prevalence, incidence, behaviour and communication survey 2008: a turning tide among teenagers? Cape Town, South Africa: HSRC Press, 2009.

20. Ministry of Health and Child Welfare Zimbabwe, Zimbabwe National Family Planning Council, National AIDS Council Zimbabwe, and US Centers for Disease Control and Prevention. The Zimbabwe young adult survey 2001-2002. Harare, Zimbabwe: Ministry of Health and Child Welfare and US Centers for Disease Control and Prevention, 2004.

21. Rehle TM, Hallett TB, Shisana O, et al. A decline in new HIV infections in South Africa: estimating HIV incidence from three national HIV surveys in 2002, 2005 and 2008. PloS One 2010;5:e11094. 
22. Gregson S, Garnett GP, Nyamukapa CA, et al. HIV decline associated with behavior change in eastern Zimbabwe. Science 2006;311:664-6.

23. Hallett TB, Gregson S, Mugurungi 0 , et al. Assessing evidence for behaviour change affecting the course of HIV epidemics: a new mathematical modelling approach and application to data from Zimbabwe. Epidemics (in press).

24. Gouws $\mathbf{E}$, Stanecki KA, Lyerla $\mathrm{R}$, et al. The epidemiology of HIV infection among young people aged 15-24 years in southern Africa. AIDS 2008;22(Suppl 4): S5-16.

25. Hallett TB, Stover J, Mishra V, et al. Estimates of HIV incidence from householdbased prevalence surveys. AIDS 2010;24:147-52

26. Zaba B, Todd J, Biraro S, et al. Diverse age patterns of HIV incidence rates in Africa. Oral Abstract TUAC0201. XVIlth International AIDS Conference. Mexico, 3-8 August 2008.

27. Ferrand RA, Corbett EL, Wood R, et al. AIDS among older children and adolescents in southern Africa: projecting the time course and magnitude of the epidemic. AIDS 2009;23:2039-46.

28. Garnett GP, Gregson S, Stanecki KA. Criteria for detecting and understanding changes in the risk of HIV infection at a national level in generalised epidemics. Sex Transm Infect 2006;82(Suppl 1):i48-51.
29. Hallett TB, White PJ, Garnett GP. Appropriate evaluation of HIV prevention interventions: from experiment to full-scale implementation. Sex Transm Infect 2007:83(Suppl 1):i55-60.

30. Cleland J, Boerma JT, Carael M, et al. Monitoring sexual behaviour in general populations: a synthesis of lessons of the past decade. Sex Transm Infect 2004:80(Suppl 2):ii1-7.

31. Slaymaker $\mathbf{E}$. A critique of international indicators of sexual risk behaviour. Sex Transm Infect 2004;80(Suppl 2):ii13-21.

32. Garnett GP, Garcia-Calleja JM, Rehle $T$, et al. Behavioural data as an adjunct to HIV surveillance data. Sex Transm Infect 2006;82(Suppl 1):i57-62.

33. Catania JA, Gibson DR, Chitwood DD, et al. Methodological problems in AIDS behavioral research: influences on measurement error and participation bias in studies of sexual behavior. Psychol Bull 1990;108:339-62.

34. Gregson S, Gonese E, Hallett TB, et al. HIV decline in Zimbabwe due to reductions in risky sex? Evidence from a comprehensive epidemiological review. Int J Epidemiol 2010;39:1311-23.

35. UNAIDS/WHO Working Group on Global HIV/AIDS and STI Surveillance. Guidelines for measuring national HIV prevalence in population based surveys. Geneva: UNAIDS and World Health Organization, 2005. 
7. Joyce PW, Haye KR, Ellis ME. Syphilitic retinitis in a homosexual man with concurrent HIV infection: case report. Genitourin Med 1989;65:244-7.

8. Kleiner RC, Najarian L, Levenson J, et al. AIDS complicated by syphilis can mimic uveitis and Crohn's disease. Case report. Arch Ophthalmol 1987;105:1486-7.

9. Levy JH, Liss RA, Maguire AM. Neurosyphilis and ocular syphilis in patients with concurrent human immunodeficiency virus infection. Retina 1989;9:175-80.

10. Moloney G, Branley M, Kotsiou G, et al. Syphilis presenting as scleritis in an HIVpositive man undergoing immune reconstitution. Clin Experiment Ophthalmol 2004;32:526-8.

11. Pleimes $\mathbf{M}$, Hartschuh W, Kutzner $\mathrm{H}$, et al. Malignant syphilis with ocular involvement and organism-depleted lesions. Clin Infect Dis 2009;48:83-5.

12. Rodriguez-Diaz E, Moran-Estefania M, Lopez-Avila A, et al. Clinical expression of secondary syphilis in a patient with HIV infection. J Dermatol 1994;21:111-16.

13. Thami GP, Kaur S, Gupta R, et al. Syphilitic panuveitis and asymptomatic neurosyphilis: a marker of HIV infection. Int J STD AIDS 2001;12:754-6.

14. Zaidman GW. Neurosyphilis and retrobulbar neuritis in a patient with AIDS. Ann Ophthalmol 1986:18:260-1.

15. Zambrano W, Perez GM, Smith JL. Acute syphilitic blindness in AIDS. J Clin Neuroophthalmol 1987:7:1-5.

16. Woods AC. Syphilis of the eye. Am J Syph Gonor Vener Dis 1943:27:133.

17. Hogan MJ, Zimmerman LE. Opthalmic pathology. 3rd edn. Philadelphia: WB Saunders, 1968.

18. Moore JE. Syphilitic iritis. Am J Ophthalmol 1931:14:110-26.

19. Browning DJ. Posterior segment manifestations of active ocular syphilis, their response to a neurosyphilis regimen of penicillin therapy, and the influence of human immunodeficiency virus status on response. Ophthalmology 2000;107:2015-23.

20. McLeish WM, Pulido JS, Holland S, et al. The ocular manifestations of syphilis in the human immunodeficiency virus type 1-infected host. Ophthalmology 1990;97:196-203

21. Maves RC, Cachay ER, Young MA, et al. Secondary syphilis with ocular manifestations in older adults. Clin Infect Dis 2008;46:e142-5.

22. Kunkel J, Schurmann D, Pleyer U, et al. Ocular syphilis-indicator of previously unknown HIV-infection. J Infect 2009;58:32-6.

23. Ormerod LD, Puklin JE, Sobel JD. Syphilitic posterior uveitis: correlative findings and significance. Clin Infect Dis 2001:32:1661-73

24. Becerra LI, Ksiazek SM, Savino PJ, et al. Syphilitic uveitis in human immunodeficiency virus-infected and noninfected patients. Ophthalmology 1989;96:1727-30.

25. Tamesis RR, Foster CS. Ocular syphilis. Ophthalmology 1990;97:1281-7.

26. McCall MB, van Lith-Verhoeven $\mathrm{JJ}$, van Crevel $\mathrm{R}$, et al. Ocular syphilis acquired through oral sex in two HIV-infected patients. Neth J Med 2004;62:206-8.

27. Ghanem KG, Moore RD, Rompalo AM, et al. Neurosyphilis in a clinical cohort of HIV1-infected patients. AIDS 2008;22:1145-51.

28. Fonollosa A, Giralt J, Pelegrin L, et al. Ocular syphilis-back again: understanding recent increases in the incidence of ocular syphilitic disease. Ocul Immunol Inflamm 2009:17:207-12.
29. Balba GP, Kumar PN, James AN, et al. Ocular syphilis in HIV-positive patients receiving highly active antiretroviral therapy. Am J Med 2006;119:448. e21-5.

30. Doris JP, Saha K, Jones NP, et al. Ocular syphilis: the new epidemic. Eye 2006;20:703-5.

31. Kuo IC, Kapusta MA, Rao NA. Vitritis as the primary manifestation of ocular syphilis in patients with HIV infection. Am J Ophthalmol 1998;125:306-11.

32. Li J, Tucker JD, Lobo A, et al. Ocular syphilis among HIV-infected individuals. Clin Infect Dis 2004:62:206-8.

33. Parc CE, Chahed S, Patel SV, et al. Manifestations and treatment of ocular syphilis during an epidemic in France. Sex Transm Dis 2007;34:553-6.

34. Passo MS, Rosenbaum JT. Ocular syphilis in patients with human immunodeficiency virus infection. Am J Ophthalmol 1988;106:1-6.

35. Shalaby IA, Dunn JP, Semba RD, et al. Syphilitic uveitis in human immunodeficiency virus-infected patients. Arch Ophthalmol 1997:115:469-73.

36. Tran TH, Cassoux N, Bodaghi B, et al. Syphilitic uveitis in patients infected with human immunodeficiency virus. Graefes Arch Clin Exp Ophthalmol 2005:243:863-9.

37. Villanueva AV, Sahouri MJ, Ormerod LD, et al. Posterior uveitis in patients with positive serology for syphilis. Clin Infect Dis 2000:30:479-85.

38. Centers for Disease Control and Prevention (CDC). Symptomatic early neurosyphilis among HIV-positive men who have sex with men-four cities, United States, January 2002-June 2004. MMWR Morb Mortal Wkly Rep 2007:56:625-8.

39. Walsh FB, Hoyt WF. Clinical neuro-ophthalmology. Baltimore: Williams and Wilkins, 1969.

40. Whitfield R, Wirostko E. Ocular syphilis. In: Locatcher-Khorazo D, ed. Microbiology of the eve. St. Louis: Mosby Co, 1972:322-50.

41. Marra CM, Maxwell CL, Smith SL, et al. Cerebrospinal fluid abnormalities in patients with syphilis: association with clinical and laboratory features. J Infect Dis 2004:189:369-76.

42. Spoor TC, Wynn P, Hartel WC, et al. Ocular syphilis. Acute and chronic. J Clin Neuroophthalmol 1983;3:197-203.

43. Spoor TC, Ramocki JM, Nesi FA, et al. Prevalence of FTA-ABS reactivity and cerebrospinal fluid findings. J Clin Neuroophthalmol 1987;7:191-5.

44. Holmes KK. Sexually transmitted diseases. 4th edn. New York: McGraw-Hill Medical, 2008.

45. CDC. Sexually transmitted disease treatment guidelines. MMWR Morb Mortal Wkly Rep 2006;55:R-7.

46. Fathilah J, Choo MM. The Jarisch-Herxheimer reaction in ocular syphilis. Med J Malaysia 2003;58:437-9

47. Danesh-Meyer H, Kubis KC, Sergott RC. Not so slowly progressive visual loss. Surv Ophthalmol 1999;44:247-52.

48. Wilhelmus K, Lukehart SA. Syphilis. In: Pepose J, Holland G, Wilhelmus K, eds. Ocular infection and immunity. Philadelphia: Mosby, 1996:1437-146.

\section{Correction}

The International Group on Analysis of Trends in HIV Prevalence and Behaviours in Young People in Countries most Affected by HIV. Trends in HIV prevalence and sexual behaviour among young people aged 15-24 years in countries most affected by HIV. Sex Transm Infect 2010;86:ii72-ii83. doi:10.1136/sti.2010.044933.

The published version of this article contained errors that have since been corrected on the online version. The journal apologises for this mistake.

Sex Transm Infect 2011:87:8. doi:10.1136/sti.2010.044933corr1 